\title{
Nephroprotective Potential Compounds from Leaves Extracts of Andrographis Paniculata
}

\author{
Article by K. Padmalochana ${ }^{1}$ and M.S. Dhana Rajan ${ }^{2}$ \\ ${ }^{1}$ Research Scholar, Bharathiar University, Coimbatore, Tamil Nadu, India \\ ${ }^{2}$ Registrar, Texila American University, Guyana, South America \\ E-mail: kpadmalochana@gmail.com ${ }^{1}$
}

\begin{abstract}
Nephrotoxicity is the third most common problem of the renal system. Medicinal plants potentially useful for the treatment of severe renal disorders. In the present study, the effect of aqueous, ethanol and acetone extract of Andrographis paniculata leaves was evaluated by pretreating three groups of rat animals. Renal failure was induced by antibiotic drug gentamicin which was orally administered to group II animals and untreated control model was maintained. After oral administration for 10 days, serum levels of urea, uric acid, creatinine and total protein were assayed. All the biochemical parameters were significantly controlled $(p<0.01$ and $p<0.001)$ on $10^{\text {th }}$ day after the treatment of aqueous, ethanol and acetone extracts as compared than the gentamicin induced nephrotoxic animals $(p<0.05)$. Maximum nephroprotection was offered by the ethanol extract of A. paniculata leaves $(p<0.001)$. The histological structure of renal was observed by staining with haemotoxylin- eosin viewed using light microscope. Gentamicin treated animals showed acute tubular necrosis due the injury in kidney. In aqueous, ethanol and acetone extract treated animals showed histopathological changes in renal revealed the nephroprotective activity of A. paniculata leaves. Finally, ethanol extract of A. paniculata was more suitable for nephroprotective action against gentamicin induced renal failure was evidenced by biochemical estimation and by restoration of histological changes of renal system.
\end{abstract}

Keywords: Kidney, Nephroprotection, Andrographis paniculata, Herbal Medicine.

\section{Introduction}

Kidney is the complex and major organ of our body perform several important functions like formation of urine, water and salt metabolism, acid-base balance, regulation of blood calcium level ${ }^{[1]}$ and secretion of hormones. ${ }^{[2]}$ Kidney affected by the diseases are mainly kidney blockage and kidney stones. Major types of stones in kidney are calcium stones, stuvite stones, uric acid stones and cysteine stones. ${ }^{[3]}$ Acute renal failures and chronic renal failure are common and serious problems. Acute renal failure is reversible loss of kidney function whereas chronic renal failure is irreversible loss of kidney function. ${ }^{[4]}$

Nephrotoxicity is one of the major kidney problems caused by drug or toxin ${ }^{[5]}$ Drugs, diagnostic agents, chemical reagents and heavy metals are well known to be nephrotoxic. ${ }^{[6]}$ In recent years, development of modern medical, and surgical practices has been followed for the treatment of renal failure like haemodialysis, renal transplantation and chemotherapy. These procedures are complicated and high cost has been utilized to cure the kidney damage. So that the traditional medicine using herbal plant is best method than the conventional method. However, when using these chemotherapy method may induce the side effects to the body. ${ }^{[7]}$ Nephroprotective agents are the substances which possess protective activity against nephrotoxicity. Drugs like gentamicin, cisplatin, cyclosporine, Carbon tetrachloride are common source of acute kidney injury. Gentamicin is an amino glycoside antibiotics used for the treatment of Gram negative bacterial infections. Overdose of gentamicin causes renal damage. It may give serious side effects while continuous consuming at higher concentrations.

Medicinal plants are have curative properties and therapeutic values due to the presence of various complex phytochemical compounds. This traditional medicines are assuming greater important because of very effective, safer, locally available, and no side effects. ${ }^{[8,9]}$ A. paniculata, a member of the family of Acanthaceae is locally and commonly available plant in India. It is commonly called as "nilavembu or siriyanangai" in Tamil and "King of bitters" in English. It has been shown hepatoprotective, anti- 
DOI: 10.21522/TIJBMS.2016.02.02.Art003

ISSN: $2519-500 \mathrm{X}$

parasitic, antioxidant anti-inflammatory and antimicrobial activity. And used helps in malaria treatment and treatment of cancer. ${ }^{[10]}$ In this study reported that curative properties of the medicinal plant Andrographis paniculata against nephrotoxicity induced by gentamicin in albino rats. Nephroprotective activity was confirmed by examine biochemical tests for urea, uric acid creatinine and protein level in blood and histopathological studies carried out using light microscopic observations.

\section{Materials and methods}

\section{Preparation of plant leaf extracts}

Leaves of Andrographis paniculatawere collected and shade dried for 3-5 days and grinded into powder. Aqueous extract was prepared by adding dried powder into $100 \mathrm{ml}$ water and incubate overnight. $100 \mathrm{~g}$ dry powder was extracted with $80 \%$ ethanol at $55^{\circ} \mathrm{C}$ for 24 hours in soxhlet apparatus. Acetone extract was prepared by mixing of dried leaf powder with the $80 \%$ acetone. Solvent elimination was done at room temperature and stored. The resulting aqueous, ethanol and acetone extracts were then used for nephroprotective activity.

\section{Experimental Design for nephroprotective Activity of Andrographis paniculata}

Adult male Wister albino rats maintained at the college weighing between $150 \mathrm{~g}-170 \mathrm{~g}$ were used for the nephroprotective studies. Animals were divided into six groups insix rats each. Group I (Normal): Orally received distilled water for 10 days.

Group II (Induced): Orally received Gentamicin ( $80 \mathrm{mg} / \mathrm{kg}$ body weight) only for 10 days. Group III (Standard): Orally received Cystone $(20 \mathrm{mg} / \mathrm{kg}$ body weight) along with gentamicin $(80 \mathrm{mg} / \mathrm{kg}$ body weight) for 10 days.

Group IV (Treatment): Orally received aqueousleaf extract (300mg/kg body weight) along with Gentamicin ( $80 \mathrm{mg} / \mathrm{kg}$ body weight) for 10 days.

Group V (Treatment): Orally received ethanol leaf extract $(300 \mathrm{mg} / \mathrm{kg}$ body weight) along with Gentamicin ( $80 \mathrm{mg} / \mathrm{kg}$ body weight) for 10 days.

Group VI (Treatment): Orally received acetone leafextract (300mg/kg body weight) along with Gentamicin ( $80 \mathrm{mg} / \mathrm{kg}$ body weight) for 10 days.

Cystone was used as positive control for comparing nephroprotective potential of different leaves extract of A. paniculata. Gentamicin is act as nephrotoxin which induces the kidney damage.

\section{Histopathological and biochemical study}

After 10 days, all animals from every group were sacrificed and separated the kidneys by dissection procedure. Pieces of kidneys obtained from each group were immediately fixed in $10 \%$ formalin solution. The fixed formalin fixed kidneys were embedded in paraffin and serial section were made and stained with haemotoxylin and eosin. The stained sections were examined under light microscope. Blood samples were collected from jugular vein. Serum was separated from the blood for the analysis of the parameters like Blood Urea ${ }^{[11]}$, Uric Acid ${ }^{[12]}$, Creatinine ${ }^{[13]}$ and Total Protein. ${ }^{[14]}$

\section{Statistical analysis}

Data were analyzed using one way Analysis of Variance (ANOVA) and expressed as mean \pm S.E.M. Statistical significance was fixed $\mathrm{p}<0.05$.

\section{Results and discussion}

\section{Biochemical studies}

The nephroprotective activity of aqueous, ethanol and acetone extract of A. paniculata leaves was assessed against nephrotoxicity induced using gentamicin in albino rats. The nephroprotective activity was determined by biochemical tests and histopathological studies. Table 1 shows the changes of urea and uric acid level in blood. Blood urea and blood uric acid in the control (group I) was estimated to be $30.16 \pm 1.72 \mathrm{mg} / \mathrm{dl}$ and $5.08 \pm 0.21 \mathrm{mg} / \mathrm{dl}$, respectively. In the negative control i.e. group II animals received only gentamicin which shows level of urea and uric acid in blood to be $59.00 \pm 2.19 \mathrm{mg} / \mathrm{dl}$ and $8.25 \pm 0.54 \mathrm{mg} / \mathrm{dl}$, respectively. Group IV, V and VI animals received gentamicin along with aqueous leaf extract, ethanol and acetone extract demonstrated a significant increase $(p<0.05$ to $p<0.001)$ in 
blood urea and uric acid as compared with negative control group. In the ethanol treated groups shows most significant changes $(\mathrm{p}<0.001)$ in urea and uric acid recorded as $33.28 \pm 0.54 \mathrm{mg} / \mathrm{dl}$ and $5.21 \pm 0.12 \mathrm{mg} / \mathrm{dl}$ as compared with aqueous and acetone extract (Figure 1).

Creatinine concentrations in blood was significantly increased $(p<0.05)$ in the gentamicin treated negative control group of animals $(2.88 \pm 0.11 \mathrm{mg} / \mathrm{dl})$ compared to the normal animals indicating the induction of severe nephrotoxicity. Treatment with plant extracts of A. paniculata showed significant $(\mathrm{p}<0.01$ and $\mathrm{p}<0.001)$ increase in creatinine concentrations. Ethanol extract treated animals showed increased significant changes $(\mathrm{p}<0.001)$ recorded as $0.82 \pm 0.54 \mathrm{mg} / \mathrm{dl}$ concentrations of creatinine, indicates that nephrotoxicity curative properties of A. paniculata leaves (Table 2).

Normal total protein level was observed in group I animals. Gentamicin treated group II animals showed low amount of secretion of total proteins $(\mathrm{p}<0.05)$ as compared to normal animals. This low protein level in serum is probably due to an inhibitory action of protein synthesis induction of tissue damage and may leads to increased excretion of protein in urine (Ramesh et al 2014). Treatment with the plant extracts of $A$. paniculata (group IV, V and VI) showed ( $<<0.01$ and $\mathrm{p}<0.001$ ) increase in concentrations of total protein compared to the gentamicin treated groups (group II) (Table 2, Figure 2).

This inhibitory action of A. paniculata leaves extract against nephrotoxin was confirmed through biochemical and histopathological studies. This activity may due to the presence of secondary metabolites like flavonoid and polypheolic compounds which may be responsible for the kidney protective activity.

\section{Figure captions}

Table 1. Effect of aqueous, ethanol and acetone extract of $A$. paniculata leaves on blood urea and uric acid in gentamicin induced nephrotoxic rats

\begin{tabular}{|l|l|l|}
\hline Parameters & $\begin{array}{l}\text { Blood } \\
\text { Urea(mg/dl) }\end{array}$ & $\begin{array}{l}\text { Blood Uric } \\
\text { acid (mg/dl) }\end{array}$ \\
\hline Group I (Normal) & $30.16+1.72$ & $5.08+0.21$ \\
\hline Group II (induced) & $59.00+2.19^{*}$ & $8.28+0.54^{*}$ \\
\hline Group III (Standard drug) & $34.83+3.06^{* *}$ & $5.95+0.21^{* *}$ \\
\hline Group IV (Aqueous) & $36.16+2.48^{* *}$ & $6.12+0.33^{* *}$ \\
\hline Group V (Ethanol) & $33.28+0.54^{* * *}$ & $5.21+0.12^{* * *}$ \\
\hline Group VI (acetone) & $39.08+0.21^{* * *}$ & $6.36+0.13^{* * *}$ \\
\hline
\end{tabular}

$* \mathbf{p}<\mathbf{0 . 0 5}, * * \mathbf{p}<\mathbf{0 . 0 1}, * * * \mathbf{p}<\mathbf{0 . 0 0 1}$ value are considered statistically significant $(\mathrm{BMRT})$

Table 2. Effect of aqueous, ethanol and acetone extract of A. paniculata leaves on creatinine and total protein levels in gentamicin induced nephrotoxic rats

\begin{tabular}{|l|l|l|}
\hline Parameters & $\begin{array}{l}\text { Creatinine } \\
(\mathbf{m g} / \mathbf{d l})\end{array}$ & $\begin{array}{l}\text { Total protein } \\
(\mathbf{m g} / \mathbf{d l})\end{array}$ \\
\hline Group I (Normal) & $0.79+0.02$ & $6.91+0.59$ \\
\hline Group II (induced) & $2.88+011^{*}$ & $3.02+0.84^{*}$ \\
\hline Group III (Standard drug) & $1.21+0.12^{* *}$ & $7.55+0.70^{* *}$ \\
\hline Group IV (Aqueous) & $1.11+0.13^{* * *}$ & $7.12+0.77^{* *}$ \\
\hline Group V (Ethanol) & $0.82+0.54^{* * *}$ & $7.91+0.12^{* * *}$ \\
\hline Group VI (acetone) & $1.38+0.21^{* *}$ & $7.56+0.13^{* * *}$ \\
\hline
\end{tabular}

$* \mathbf{p}<\mathbf{0 . 0 5}, * * \mathbf{p}<\mathbf{0 . 0 1}, * * * \mathbf{p}<\mathbf{0 . 0 0 1}$ value are considered statistically significant $(\mathrm{BMRT})$ 
DOI: 10.21522/TIJBMS.2016.02.02.Art003

ISSN: $2519-500 \mathrm{X}$

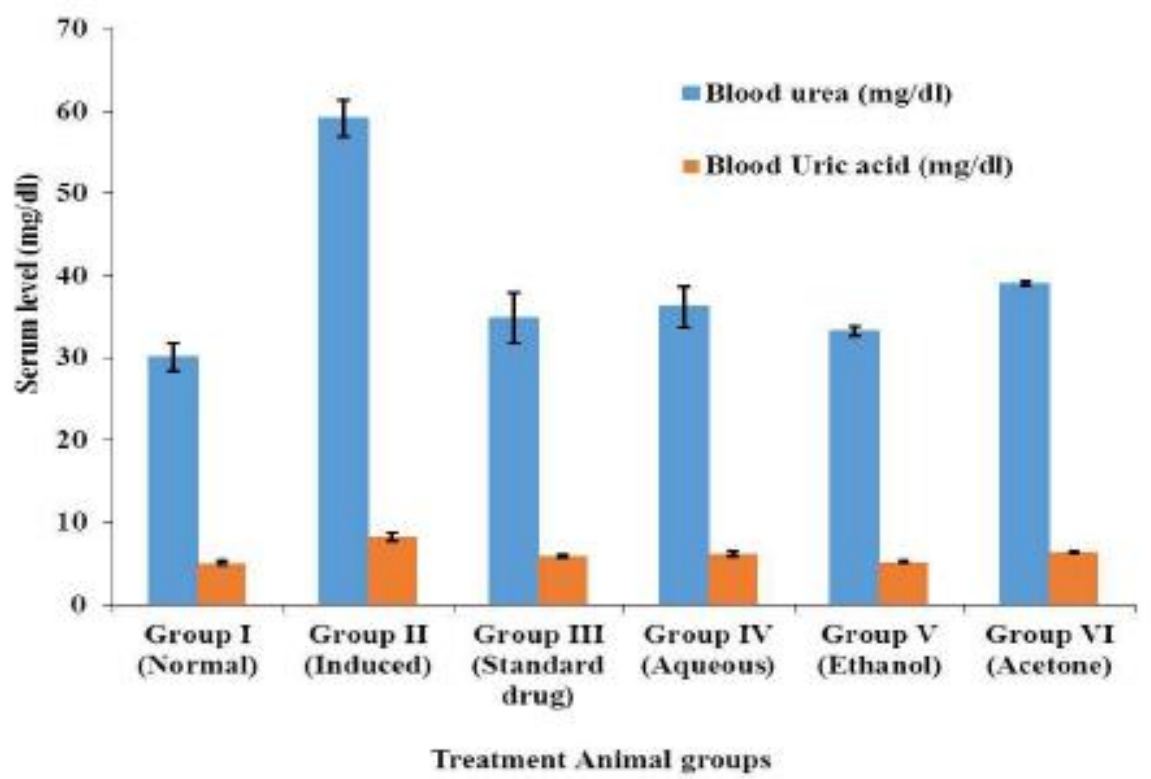

Figure 1. Effect of aqueous, ethanol and acetone A. paniculata leaves extract on the alterations of urea, and uric acid level in blood

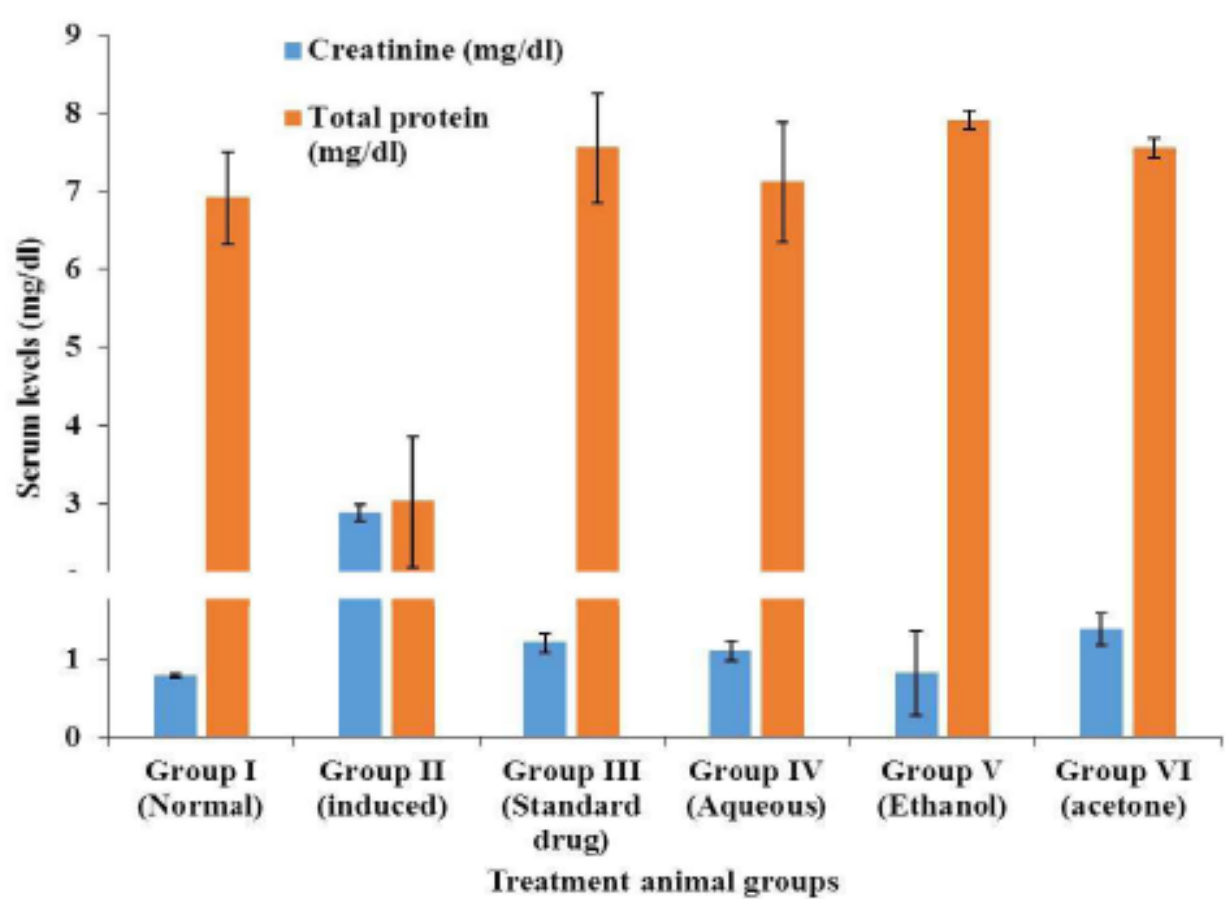

Figure 2. Effect of aqueous, ethanol and acetone A. paniculata leaves extract on the alterations of creatinine, and total protein level in blood 

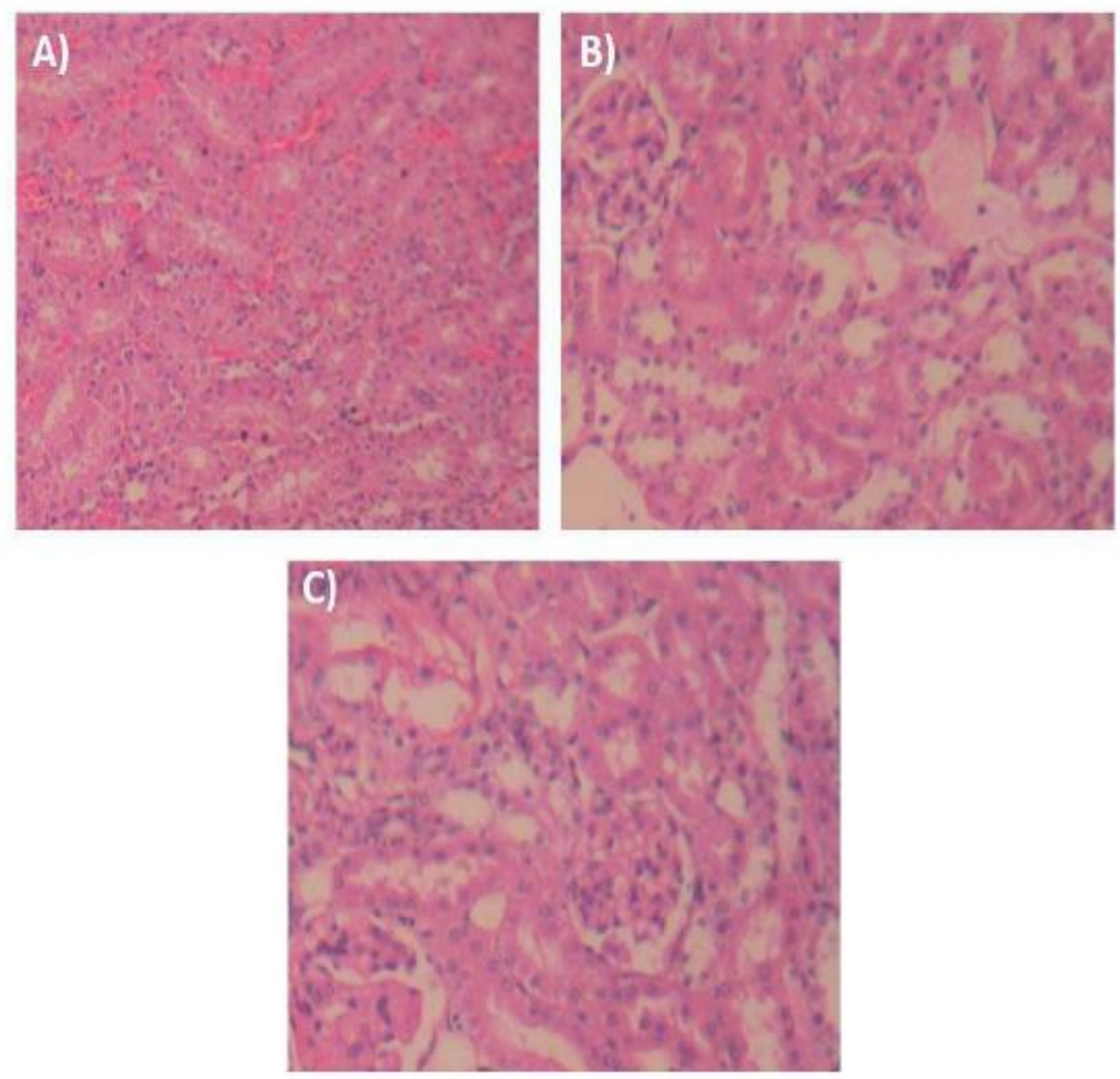

Figure 3. Sectioning of (A) normal kidney showing tubular brush borders and intact glomeruli in renal tissues without alterations (B) Representing the tubular necrosis in gentamicin treated animals (C) shows microscopic observation of normalized kidney structure on treated with cystone is a positive control 
DOI: 10.21522/TIJBMS.2016.02.02.Art003

ISSN: $2519-500 \mathrm{X}$
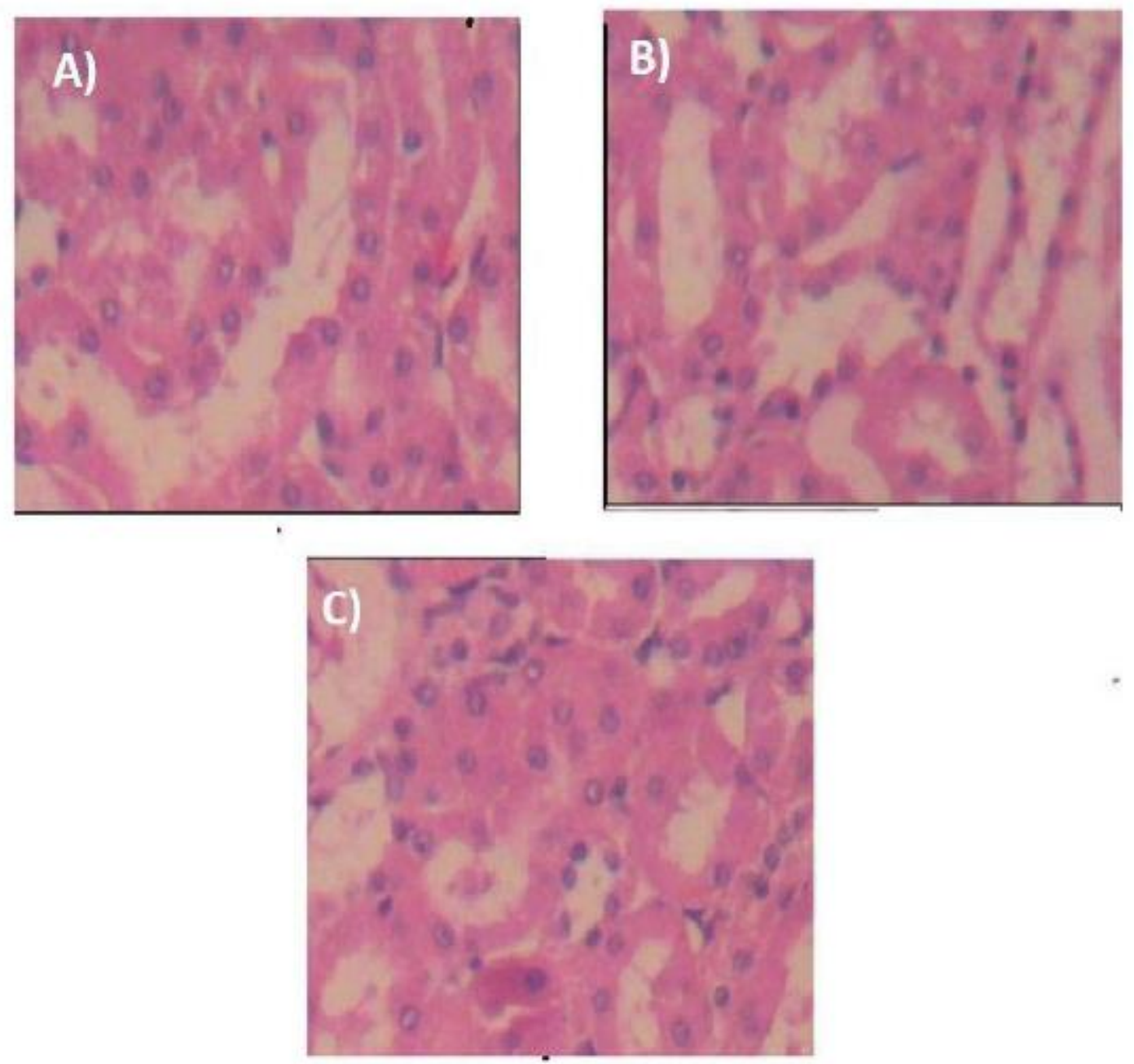

Figure 4. Shows histological structure of kidney treated with (A) aqueous extract (B) ethanol extract (C) acetone extract of A. paniculata leaves on gentamicin induced nephrotoxicity rat animals revealed normalized and restored function of renal system

\section{Conclusion}

Herbal medicine have useful for the development of effective therapy to treat variety of diseases. Nephrotoxicity induced by gentamicin in rats developed significant kidney injuries was estimated from increased levels of urea, uric acid, and creatinine $(\mathrm{p}<0.05)$ and decreased levels of total protein in blood serum. These parameters were more significantly $(\mathrm{p}<0.001)$ altered and restored by oral supplementation of aqueous, ethanol and acetone extract of $A$. paniculata leaves to gentamicin intoxicated rats. Our present study clearly indicated a significant nephroprotective activity by normalize the elevated biochemical and restoration of renal system using with the extract of A. paniculata leaves and supported the traditional usage of the plant in the medicinal system.

\section{References}

[1]. Anil Kumar, Jyotsna Dora, Anup Singh and Rishikant Tripathi, A review on king of bitter (Kalmegh), International Journal of Research in Pharmacy and Chemistry, 2012; 2(1): 116-124.

[2]. Alam M, Khan H, Samiullah L, and Shakir Jamil S, Nephroptrotective activities of herbal plants and their products- a review, International Journal of Pharmaceutical Research and Development, 2013; 5(9): 032-049.

[3]. Boneses RN and Taussk HA On the colorimetric determination of creatinine by the Jaffe reaction. J. Biol. Chem, 1945; 158: 581-591.

[4]. Bhavani R, Nandhini S, Rojalakshmi B, Shobana Rand Rajeshkumar S, Effect of noni (Morindacitrifolia) extract on treatment of ethylene glycol and ammonium chloride induced kidney disease, International Journal of Pharma Sciences and Research, 2014; 5(6): 249-256. 
[5]. Gardner CR, Laskin JD, Dambach DM, Sacco M, Durham SK, Bruno Mk, Choen SD, Gordon MK, Gerecke DR, Zhou P and Laskin DL. Reduced hepatotoxicity of acetaminophen in mice lacking inducible nitric oxide synthase: potential role of tumor necrosis factor-alpha and interleukin-10. Toxicol. Appl. Pharmacol., 2002; 184: 27-36.

[6]. Hall JE. Text Book of Medical Physiology. 12 ed. Philadelphia: Saunders Elsevier, 2011; 307-326.

[7]. Klose S., Stoltz M., Munz E., Portenhauser R., Determination of uric acid on continuous flow (Autoanlyser II and SMA) systems with a uricase/phenol/ 4.amino phenazine color test. ClinChem, 1978; 24(2): $250-255$.

[8]. Lowry O H., Rosebrough N J., Lewisfarr A., Randall R J., Protein measurement with the Folin's phenol reagent. J. BiolChem, 1951; 193: 265-275.

[9]. Mohana Lakshmi S, UshaKiran Reddy T, and Sandhya Rani KS,A review on medicinal plants for nephroprotective activity, Asian J Pharm Clin Res, 2012; 5(4): 8-14

[10]. Movaliya V, Khamar D and Manjunath Setty M, Nephro-protective activity of aqueous extract of Aerva javanica roots in Cisplatin induced renal toxicity in ratsPharmacologyonline1, 2011; 68-74.

[11]. Natelson S., Scott ML., Beffa C., A rapid method for the estimation of urea in biological fluid. Am JClin Pathol, 1951; 21: 275-281.

[12]. Newton J, Hoefle D, Gemborys M, Mugede G and Hook J, Metabolism and excretion of a glutathione conjugate of acetaminophen in the isolated rat kidney. J. Pharmacol. Exp. Ther., 1996; 237: 519-524.

[13]. Porter GA and Bennett WM. Nephrotoxic acute renal failure due to common drugs American journal of Physiology, 1981; 241(7): F1-F8.

[14]. Okokon JE, Nwafor PA, Noah K, Nephroprotective effect of Croton zambesicusroot extract against gentamicin-induced kidney injury, Asian Pacific Journal of Tropical Medicine, 2011; 969-972.

[15]. Ramesh K, Manohar S and Rajeshkumar S, Nephroprotective activity of Ethanolic Extract of Orthosiphon stamineus Leaves on Ethylene Glycol induced Urolithiasis in Albino Rats, Int.J.PharmTech Res, 2014, 6(1): 403408.

[16]. Singh RP, Shokala KP, Pandey BL Singh RG, Usha Singh RH. Recent Approach in Clinical Experimental Evaluation of Diuretic Action of Punarnava (B. diffusa) with Special Reference to Nephrotic Syndrome. Journal of Research and Education in India Medicine, 1992; 7(1): 29-35.

[17]. Sarumathy K, M.S. Dhana Rajan, T. Vijay, J. Jayakanthi, Evaluation of phytoconstituents, nephroprotectiveand antioxidant activities of Clitoriaternatea, Journal of Applied Pharmaceutical Science, 2011; 01(05): 164-172.

[18]. Saumya R. pani, Satyaranjan Mishra, Sabujsahoo and prasana K. Panda, Protective effect of herbal drug in cisplatin induced nephrotoxicity, Indian journal of pharmacology, 2011; 43(2): 200-202.

[19]. Trumper L, Monasterolo LA and Elias MM. Probenecid protects against in vitro acetaminophen induced nephrotoxicity in male Wistar rats. J. Pharmacol. Exp. Therapeat., 1998; 283: 606-610. 